\title{
Articles
}

\section{Changes in Speech Acts During Study Abroad Programs: Japanese Students Studying in the United States and Australia}

\section{Emi Fukasawa \\ Center for Language Education and Research, Sophia University}

This paper details an exploration into changes in speech acts and interactions in English (i.e., requests and refusals) in nonclassroom interactions before and after study abroad programs. I transcribed role-plays of two Japanese students before and after they completed study abroad programs in the United States and Australia, carried out periodic online interviews during their stays overseas, and conducted follow-up interviews once they returned to Japan. The results show that changes in the use of expressions occurred for three reasons: 1) input-initiated changes from noticing form-meaning-function relationships, 2) instruction-initiated changes, and 3) output-initiated changes. Because some of the changes were problematic and led to misunderstandings or impoliteness, I conclude that learning from natural input alone is not sufficient to learn how to navigate between function and situation. Therefore, the results suggest that explicit feedback and instructions in classrooms are important before and during study abroad programs.

本論文は留学前後の教室外のインタラクションにおける、英語での発話行為（依頼と断 り）とインタラクションの変化を探る。アメリカとオーストラリアへ留学前後の2名の日 本人学生のロールプレイを書き起こし、留学中に定期的なオンラインインタビューを実施

JALT Journal, Vol. 41, No. 2, November 2019 
し、帰国後にフォローアップインタビューを行った。その結果、言語使用の変化には3つ の理由があることが示された：1）表現形式・意味・機能の気づきから起こるインプット による変化、2）指導による変化、3）アウトプットによる変化である。これらの変化の中 には誤解や失礼さを招くという問題も見られることから、機能と状況のバランスの取り方 を学ぶためには自然なインプットだけでは不十分であると言える。したがって、本研究の 結果は留学前と留学中に教室での明示的なフィードバックと指導が重要であることを示唆 している。

Keywords: nonclassroom interaction; noticing; speech acts; study abroad programs

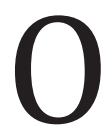
ne of the advantages to studying abroad is the ability of students to obtain enormous exposure to a foreign language, and previous studies have generally assumed that study abroad programs aid language acquisition because students have daily access to native speakers (Segalowitz \& Freed, 2004). The amount of exposure to a foreign language is one of the biggest differences between learning in ESL and EFL contexts; studying abroad, therefore, is a great opportunity for Japanese EFL students.

However, although previous studies have shown studying abroad to be of great benefit to language learners, researchers tend to examine the effectiveness of study abroad programs quantitatively rather than qualitatively, despite the fact that language development varies depending on a learner's characteristics, environment, and so on (e.g., BardoviHarlig, 2013; Isabelli-García, 2006; Wilkinson, 1998). Therefore, it can be argued that quantitative studies cannot fully elucidate individual language development during stays abroad. Although some researchers have attempted to understand the importance of environmental factors in language acquisition (cf. Bardovi-Harlig \& Bastos, 2011; Dewey et al., 2014; Taguchi, 2008, 2012), more detailed studies are needed to fully understand language learners' pragmatic development.

Previous research has shown that language learners' input and actions affect their pragmatic competence (e.g., Hassall, 2006; Matsumura, 2003). However, these studies have not determined what specific input learners can use effectively, as researchers cannot confirm what input learners actually notice. If learners are too focused on the meaning of speech interactions outside the classroom, for example, they might not notice the rules of language, especially pragmatics, which are usually not obvious. This noticing is important in pragmatic learning; however, as Schauer (2009) noted, it can occur only if learners have already noticed the strategies or expressions used by English speakers. 


\section{Noticing and Interlanguage Pragmatics}

The process of learning is an important aspect of second language acquisition. Schmidt and Frota (1986) and Schmidt (1990; 1993; 2001) developed the noticing hypothesis, one of the predominant theories in the field, which states that "there is evidence for a relationship between what learners notice and understand about pragmatics and discourse and what is learned" (Schmidt, 1993, p. 29). Likewise, Schmidt (1990; 2001) argues that learners' noticing is a necessary condition for language learning, including the learning of pragmatics. Noticing a form-meaning-function relationship is the most fundamental aspect of noticing, and learners notice something based on the input they receive. The something refers not only to a vocabulary word or grammatical form but also to the context in which the word is used and its function. Meaning and function are both important aspects of language: Students cannot simply know a word's meaning but must also understand how it is used in a natural setting.

In the field of interlanguage pragmatics, little work has been done on noticing and the development of pragmatic competence. However, there are some exceptions. Cook (2001), for example, demonstrated that Japanese as a Foreign Language students were not aware of contextualization cues in Japanese while taking a listening test. The results suggested that noticing contextualization cues in interactions outside of the classroom is not guaranteed, even if part of an educational curriculum. Likewise, Takahashi (2005) investigated the relationships among motivation, proficiency, and pragmalinguistic awareness and found intrinsic motivation is associated with awareness of the target input. Takahashi $(2012 ; 2013)$ also investigated the relationships between individual differences (motivation and listening proficiency) and pragmalinguistic awareness. She found that learners' noticing of the target request forms in the input led to the learning of internal modifiers (e.g., "just," "really," and "at all") but did not predict the mastery of biclausal request forms (head-acts). Takahashi's (2015) later study focused more on learners' characteristics that predict awareness and learning and found that awareness of the target forms was constrained by the learners' strong communication-oriented motivation and higher listening proficiency. Takahashi (2017) extended the previous studies and found that learners who had sound grammatical competence (in other words, adequate familiarity with the target forms) could perform well in the dictation task from the beginning and use the target forms in the posttest; however, some of the students could not use the target forms even though they had similar grammatical competence. Therefore, she suggests that structural familiarity 
leads learners to detect and produce the target forms. However, the level of analysis of the form-function relationship may differ among students and therefore cause different outcomes.

In summary, even though Schmidt (1990) describes the importance of noticing in applied linguistics, the concept has not been fully discussed in interlanguage pragmatics. As Taguchi (2015) states, very little has been written on the development of noticing and the acquisition of pragmatic knowledge. Various questions remain, including how noticing interacts with the development of pragmatic competence and what kinds of noticing affect students' development of pragmatic competence especially during study abroad programs. Answering these questions could allow the learning trajectory of pragmatics to be revealed, which would promote more effective instruction in classroom settings. Therefore, there is an attempt through study to contribute to existing research by including a consideration of the relevant environmental factors (input from the surrounding secondlanguage environment) during study abroad programs. In this way, I hope to demonstrate that the differences in what learners notice out of the rich input during their study abroad period can vary their language learning outcomes. Moreover, whereas some previous studies (e.g., Kondo, 2008) are focused on examining noticing only within the context of the EFL classroom environment, I also seek to understand whether noticing is related to the development of pragmatic competence outside the classroom in an ESL environment. To that end, this study's research question is as follows: What changes occur in learners' speech act behavior during their study abroad period, and is noticing related to the changes in their speech act behavior?

\section{Methods}

\section{Participants}

Two female Japanese university students with nonEnglish majors participated in this study. Their pseudonyms are Maki and Tomoko, and they both participated in different language-focused study abroad programs. Both were selected from a larger scale study $(N=4)$ because their interactions were representative of the typical patterns that occurred. Other participants are not discussed here because of space limitations, but their interactional data also showed the same kinds of characteristics after studying abroad.

Maki was 20 years old (university junior) and majoring in marketing at the time of her participation. Before she studied abroad, her TOEIC score was 630 , and she had no previous study abroad experience. Maki's goal 
with regard to studying abroad was to be able to speak more English and experience different cultures through homestays and school activities. Maki enrolled in a language program for university students in Australia and stayed with a host family during her 6-month stay. Fortunately, the host family was very engaged and often talked with Maki and the other students living in the house. The presence of other exchange students positively affected Maki's language development as well: Regular meetings with the same people made it easier for her to use English and observe the interactions of people more proficient in English than she.

Tomoko was a sophomore journalism major when she participated in a study abroad program to the United States. Before studying abroad, she had passed the second grade of the EIKEN test, which includes an interview test and is roughly equivalent to Maki's TOEIC Listening and Reading test score (MEXT, 2016). Tomoko had previously participated in several shorter homestays in Russia, Taiwan, and Australia, but this time, she chose to live in a dormitory with roommates of various nationalities for five months. Her goal in studying abroad was to improve her English proficiency. When the program started, she was not happy about her ESL class: Many of the students came from countries where English is not spoken as a first language, and she strongly believed that English should be learned from native speakers. She thus sought opportunities to speak English outside the classroom as often as possible and regularly met with several groups of friends to do so.

\section{Speech Acts}

The data are based on part of spoken role-plays consisting of four situations with two speech acts in each: refusal and request. ${ }^{1}$ These acts were specifically chosen because they are often studied in the field of interlanguage pragmatics (e.g., Bardovi-Harlig \& Hartford, 1991; Blum-Kulka, 1982; Trosborg, 1995). At the same time, they are often used in situations in which a speaker needs to frequently modify his or her speech to seem polite. This can be a highly demanding task for second language learners, especially if they are of limited proficiency.

An additional variable has been included to differentiate the situations: the interlocutor's status. In some situations, the interlocutor is a professor and in others a friend. The level of the request's imposition, which refers to the difficulty of conducting the request, is the same for each situation. Finally, the distance between the interlocutors is set as "close" in all situations. The participants were told that, for the role-play, they know the interlocutors well and that the relationship between them is good. To confirm that the 
situational descriptions were as I intended, several researchers of applied linguistics and interlanguage pragmatics read and approved the descriptions. The role-play situations are presented in the Appendix.

\section{Data Collection}

Interlanguage pragmatics uses many different methods of data collection, depending on the research questions. In this study, role-play was used to obtain interactional data. In role-play, each speaker is given a role, and they act as if they were in the imaginary, yet realistic, situation presented. The advantage of this method is that researchers can observe the natural flow of conversation (Roever, 2011), even if it is not the same as natural interaction (Yuan, 2001).

Data collection was carried out in three phases: before, during, and after the students' study abroad period. Before studying abroad, each participant met the interlocutor, whose pseudonym was David, a native-speaking English teacher at their university. He conducted all role-plays, with the exception of Tomoko's pre-study abroad role-play, in which she met with a nonnative-speaking English teacher (E) due to a scheduling conflict. None of the participants were students of $E$ or David's classes.

During the study abroad period, the participants took part in periodic online interviews conducted in Japanese. During these interviews, they were asked about their college life and whether they had had any opportunities to practice the target speech acts. If they answered in the affirmative, they were then asked to explain these in detail. After the study abroad program, the students participated in the same role-play session with David. Finally, the author conducted a follow-up interview in Japanese with each participant. The interview was conducted three or four months after the post-study abroad role-play because the participants were unable to attend the interview during the school holidays, when they returned to their hometowns. They were asked to explain why they chose certain expressions, in which situations they learned new phrases, and so on based on the transcription of their role-play sessions. The author transcribed all the role-plays, translated the interviews, and asked an applied linguistics researcher who was fluent in English to check their accuracy.

\section{Results}

The study found that the participants were adapting their language based on three sources: observation, instruction, and output. 


\section{Observation}

Excerpt 1 is part of Maki's pre-study abroad role-play. She was asked to refuse a teacher's invitation to have lunch with other class members at the end of the semester.

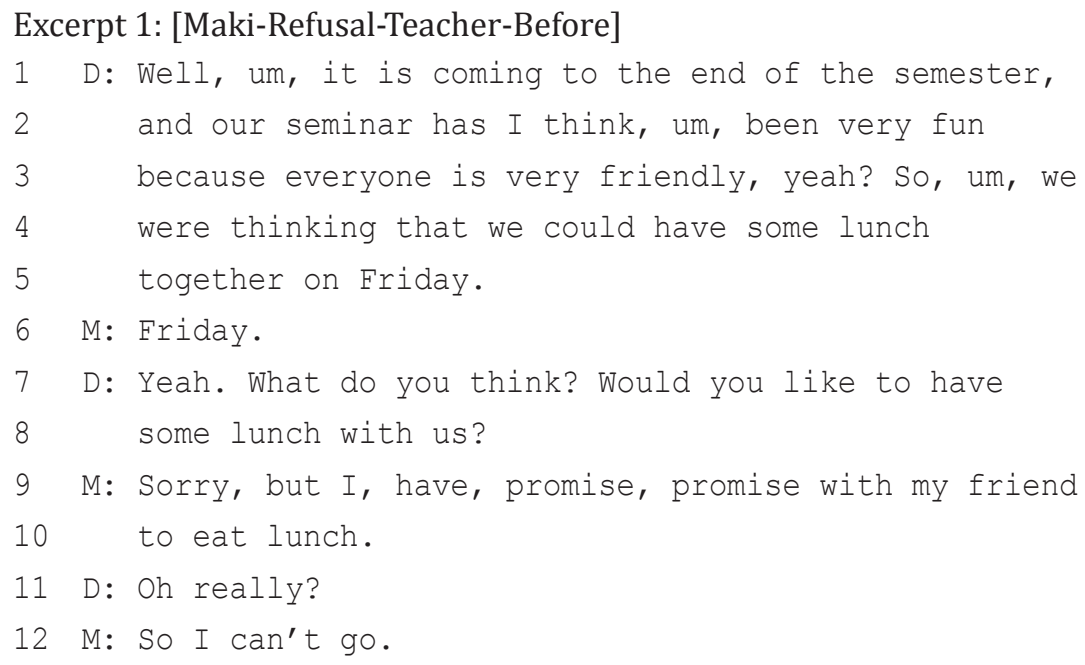

At first, in reply to the invitation from David, Maki says that she had made an appointment with other friends before receiving the teacher's invitation (Excerpt 1, lines 9-10). This is both an apology and account before the actual refusal. Then, in line 12 (Excerpt 1), Maki refused explicitly: "I can't go."

After her study abroad program, Maki uses a different expression to refuse the invitation (Excerpt 2):

\section{Excerpt 2: [Maki-Refusal-Teacher-After]}

1 D: Yeah, ah, I wanted to ask you a question about ah

2 this Friday.

3 M: Hum.

4 D: Uh, since, um, oh, our class is gonna be finishing

5 soon,

6 M: Yeah.

7 D: I was wondering if you'd like to join us in our 


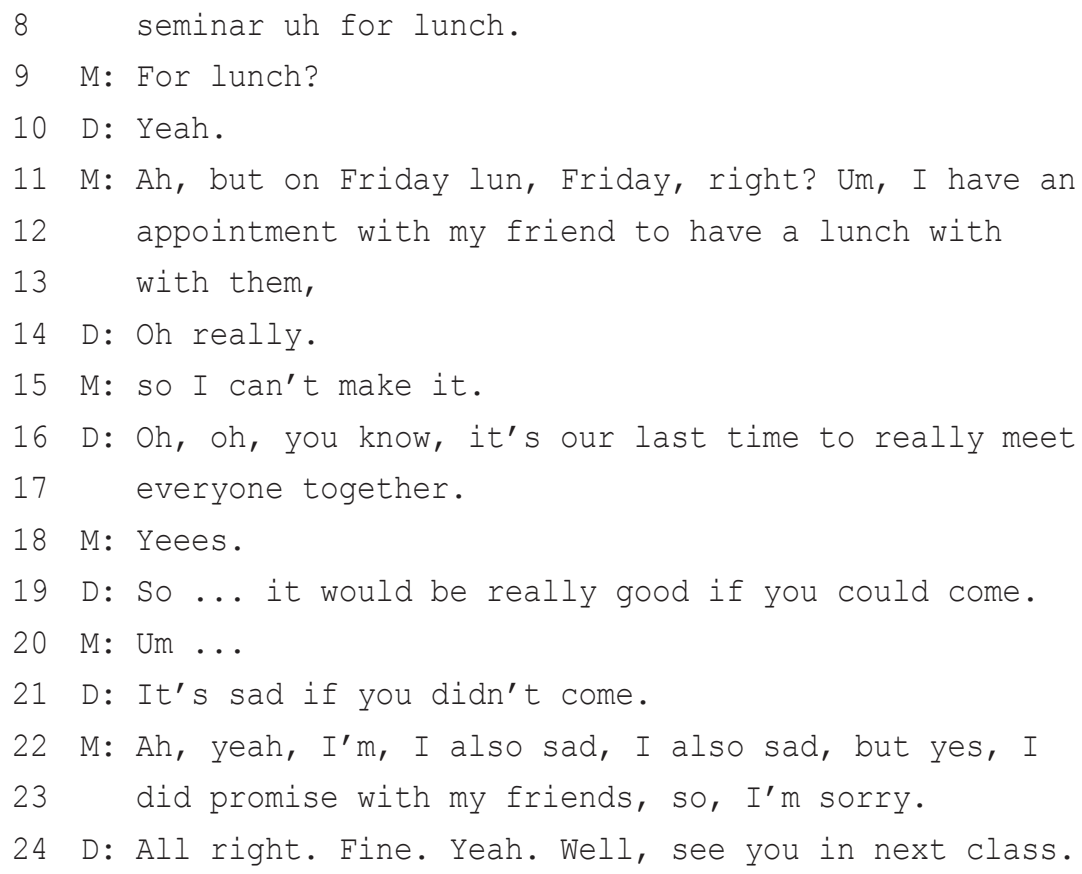

In lines 11-13 (Excerpt 2), Maki gave a reason for not attending, and in line 15 (Excerpt 2), she followed this with an explicit refusal: "I can't make it." This is a new expression that only appears after her study abroad program in place of the "I can't go" she used before studying abroad. It sounds like she wanted to go but could not, unlike "I can't go," which is more abrupt. When asked about this phrase in her follow-up interview, Maki said,

I used it to mean "I cannot go." During the study abroad period, I had a similar experience. When I emailed my classmate "can you come today?" and she replied "I can't make it." Then I understood the meaning of this expression by context.

According to her comment, she learned this phrase from an experience with her friend. It was not due to direct classroom instruction, but she understood the way to use the phrase from observing the context. Therefore, it can be said that this occasion was an example of noticing a form (Schmidt, 2001; Schmidt \& Frota, 1986). 
After David replied, "It's sad if you didn't come" (Excerpt 2, line 21), Maki repeated part of his utterance, saying, "I also sad, I also sad" (Excerpt 2, line 22). In this utterance, we can see that she accepted his feeling of regret by repeating his phrase. It shows that even if she understood how he was feeling, she still, regrettably, needed to refuse the invitation. I also asked her about this phrasing in the follow-up interview, and she said,

I meant "I wish I could go." I wanted to express my feeling of being sorry, that is why I used this phrase. I started to use "also" quite often after I left Japan. I noticed it is used frequently from the conversations of my roommates and friends.

This explanation suggests that she wanted to express regret by using this phrase. She could have used other, similar phrases, like "I wish I could go, but...." which would have expressed the same idea. However, perhaps this was the best she could do at that time. It is interesting to note that the use of "also" (Excerpt 2, line 22) is something she learned via input during her stay, according to her comment. Although she did not mention any specific information about situational use of the word "also," it seemed that she understood the word to convey a feeling of empathy and that it could be used as a politeness strategy.

\section{Instruction}

The participants learned other new expressions as they were explicitly taught by others, whether in the classroom or by English speakers. Unlike the examples in the previous section, these words and phrases were specifically taught, not merely observed.

\section{Use of "I Understand What You Say" Before a Refusal}

Excerpt 3 is part of Maki's pre-study abroad role-play of a refusal to a friend's invitation to attend a party.

\section{Excerpt 3: [Maki-Refusal-Friend-Before]}

1 D: I was thinking about, um, I was thinking about you

2 today, because there is going to be a party Friday

3 night.

4 M: Yeah.

5 D: I think it would be nice if you could come. 
6 M: Oh ... Sorry, but I ... have to do my report in

7 library tonight, so I can't go that party. Sorry.

Maki uses the word "sorry" in refusal; however, after her study abroad program, instead of an apology, she uses a new phrase before giving her refusal, "I understand what you say" (Excerpt 4, line 10):

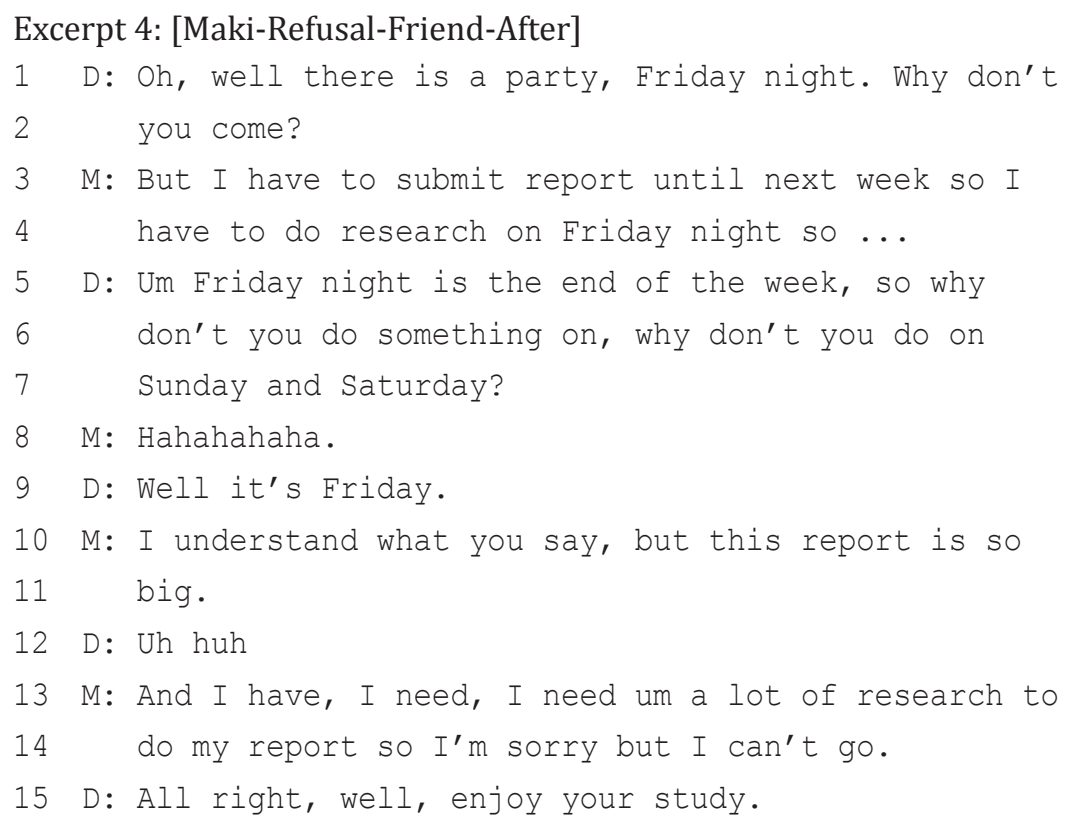

In the follow-up interview, Maki explained that she had learned this phrase of acknowledgement- "I understand what you say" - in her language class when talking about how to conduct discussions. She learned that she should accept the other person's idea before expressing her own opinion and applied this same strategy to refuse the invitation in the role-play. She realized that objecting in a classroom discussion and refusing an invitation are similar in that they both involve expressing an oppositional idea. It was her idea to apply the same strategy in a different situation. 
Use of "Can I" to Make Requests

Excerpt 5 is part of Maki's post-study abroad role-play in which she asks her friend if she can borrow his notebook to copy class notes after an absence.

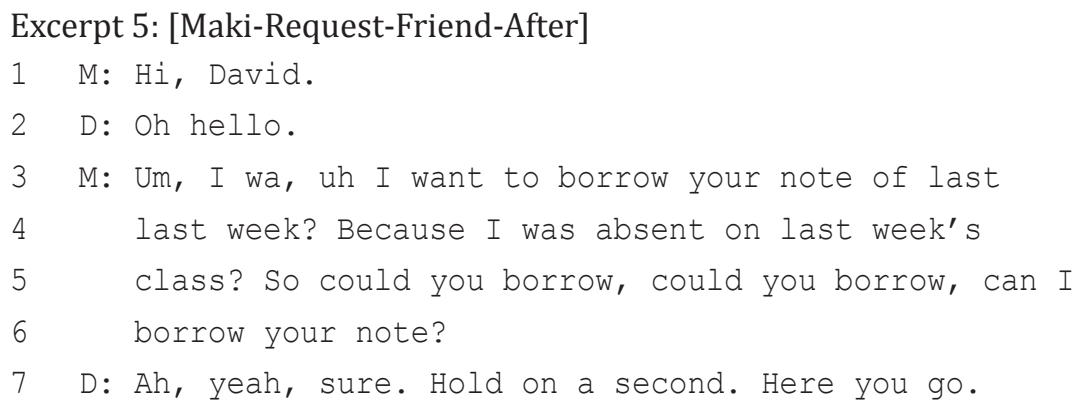

She begins the request and then gives a reason for her request (Excerpt 5, lines 3-6). In the follow-up interview, I asked about her use of the phrase "can I," which she did not use in the pre-study abroad role-play. Maki told me of two episodes related to the phrase:

During the study abroad, there was a poster in the library instructing foreign students how to ask for books: "Use 'can I borrow." I used the expression when I borrowed books. ... I also learned that requests are expressed in the question form during the study abroad. I noticed it when my host mother asked me something.

These comments show how she learned to use the phrase "can I": She both noticed its use in requests and others instructed her in its use. This is different from Schmidt's $(1990 ; 1993 ; 2001)$ proposed noticing due to input described in the previous section: Noticing is based on implicit input and requires the language learner to make an effort to notice and to be actively involved. On the contrary, Maki noticed the word's use when receiving instruction. It was more like a guided noticing, where she was shown the answer (in this case, an appropriate phrase in a particular situation). 


\section{Output}

\section{Use of "Can I" to Make Requests}

Other new expressions were used that could be traced to neither observation of input nor explicit instruction. Tomoko, for example, reported that she successfully learned new expressions during actual conversations. In the role-play after her study abroad program, Tomoko uses the phrase "can I" when making a request to a friend (Excerpt 6, line 3):

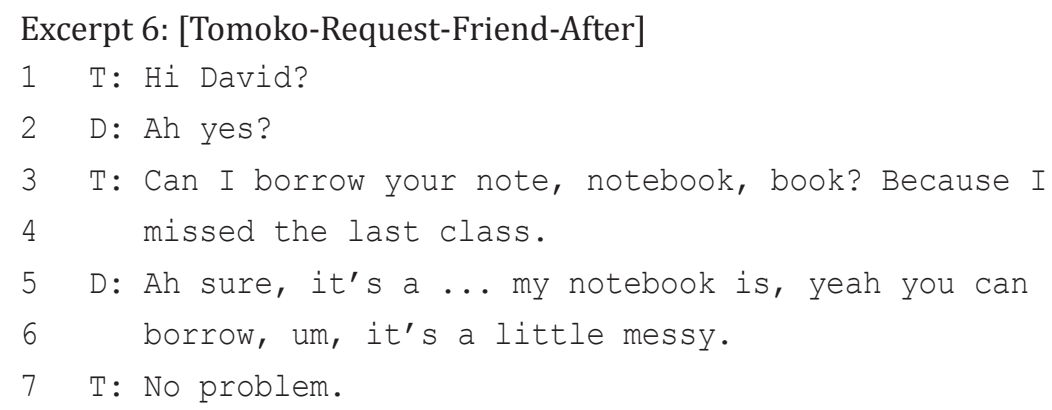

In the follow-up interview, she told me that she knew this phrase before her study abroad program but only started to regularly use it when living in the United States:

Question: Why did you use "can I"?

Tomoko: I knew this phrase, but I started to use it in the study abroad. I used "can you" before the stay, but now I use "can I" because "can you" sounds too roundabout.

Question: Why do you think so?

Tomoko: Well, because when I wanted to ask something, just saying "can I?" "may I?" worked perfectly. Of course I knew these phrases but I started to use them after I knew these phrases are useful during the stay.

The comment above shows that Tomoko indeed used "can I" frequently during her study abroad program and that she was confident about her efficient use of both "can I" and "may I." Therefore, she became comfortable using these phrases through her experiences (i.e., output), which is consistent with Swain's (1985) output hypothesis. 


\section{Use of an Introductory Remark before Making a Request}

Excerpt 7 is from a pre-study abroad role-play in which Tomoko asks to borrow a book from her teacher for a writing assignment.

\section{Excerpt 7: [Tomoko-Request-Teacher-Before]}

$1 \mathrm{~T}$ : Excuse me.

2 E: Yes.

3 T: But could you ... give me ... your book about the

4 paper?

5 E: Uh huh.

6 T: I want to read the book.

7 E: OK, you want to, ah, read this book?

8 T: Yes.

Tomoko uses two separate utterances (Excerpt 7, lines 3-4 and 6) that come together to make a request, but, her meaning remains ambiguous because of her use of the verb "give" (Excerpt 7, line 3). After her study abroad program, however, Tomoko structures her request differently as shown in Excerpt 8.

Excerpt 8: [Tomoko-Request-Teacher-After]

$1 \mathrm{~T}$ : Hi, Mr Snow.

2 D: Hello.

3 T: Hello. Can I ask you, ah, may I ask you a favor?

4 D: Ah sure. What what is it?

5 T: Um, I want, I wanna borrow your book to write the

6 paper.

7 D: Oh, OK. Yeah, that's fine. Ah what is the topic

8 that you are looking for?

9 T: Um ... I wanna write, about, cul, the culture of

10 the U.S.

11 D: Oh, OK. 
This includes a new strategy: Tomoko makes an introductory remark before her request (Excerpt 8, line 3). I asked her about this in the follow-up interview:

Question: Where did you learn, "Can I ask you, may I ask you a favor?"

Tomoko: I learned it at junior or high school in Japan. It was in the textbook. However, I had never used it before the study abroad.

Question: Why did you use it in the role-play?

Tomoko: Well, I think the phrase can make the counterpart expect what I want to say. During the stay, I said it once or twice. And I realized that the responses were very positive, I mean, they looked more cheerful saying "yes!" than when I said "excuse me" before making requests. So I thought "may I ask you a favor?" worked better than "excuse me."

Tomoko noticed that she got different reactions to requests when using different phrases and that "may I ask you a favor" worked better than "excuse me." Therefore, she learned from actually using the phrase, in other words, through her output. This was one of her learning strategies: She used trial and error to confirm whether she was using a phrase correctly. Despite making mistakes along the way, this was an effective strategy, especially when learning in a second language context, because it was easy to determine if she was using a word correctly by the reaction of native English speakers.

I also noted that her request in Excerpt 8 seemed very casual, especially when talking to a teacher, due to her use of the phrase "I wanna" (line 5). Tomoko and I also discussed this in the follow-up:

Tomoko: I heard all of my friends use it during the study abroad.

Question: The situation was to make a request to the teacher. Did you feel any differences when you did the same with your friends?

Tomoko: Well, I did not feel it much.

This implies that she learned the word "wanna" through input but could not apply it correctly to different situations. This suggests that natural input is 
not enough to notice situational differences and, therefore, instruction is also necessary.

\section{Discussion}

As stated above, the research question was: What changes occur in learners' speech act behavior during their study abroad period, and is noticing related to the changes in their speech act behavior? The role-plays and follow-up interviews revealed that students noticed some language expressions when they produced speech acts and that this was due not only to their observation of input but also due to instruction and their output experiences. Of these, learning from instruction can be more helpful or effective for study abroad students because it allows them to connect strategy (expression) with the situational context. The observation of input can be understood as noticing a form-meaning-function relationship (Schmidt, 1993). Learning from output is also very useful for study abroad students because it allows them to learn by using a phrase in a real conversation. This finding is consistent with those of Swain and Lapkin (1995), who determined that noticing occurs both in a learner's internal and external feedback as a result of producing the target language.

During the study abroad period, students experience input and output regarding specific speech acts and other interactional elements of speech (e.g., using introductory remarks). Input allows them to notice the use of specific words or phrases from other English speakers, while output provides them with situational knowledge that they can apply in different situations. At this point, if they have enough pragmalinguistic competence, which, based on Leech's (1983) distinction, refers to the linguistic resources required for performing language functions, they can choose the expressions that are appropriate to the situation in order to be polite. On the other hand, if this competence is lacking, students may end up failing to adapt to the situation, resulting in the use of somewhat strange expressions or negative transfer. Moreover, I found that, in some situations, the participants did not learn the appropriate situational uses of expressions based merely on input (e.g., Tomoko's use of the word "wanna" when speaking with her teacher). This would show a lack of sociopragmatic competence, which is the ability to choose and perform appropriate pragmatic strategies in a particular context. Therefore, natural input is limited in its ability to impart the appropriate situational use of expressions, which suggests the necessity of classroom instruction, especially negative feedback from others: Learners are not always aware of problematic language use unless they are explicitly told. 
Previous second language acquisition studies have suggested the necessity of negative feedback (e.g., Gass, 1997) and the effectiveness of explicit feedback over implicit feedback in grammar acquisition (for an overview, see Ellis, Loewen, \& Erlam, 2006), which has also been argued in relation to interlanguage pragmatics (e.g., Alcón Soler, 2012; Fukuya \& Martínez-Flor, 2008; Takahashi, 2001). On the other hand, there are some studies that show the positive effect of implicit feedback (e.g., Takahashi, 2010a, 2010b; Takimoto, 2006) and the combined effects of both (Martínez-Flor, 2012), which suggests that learners have different intervention preferences, and it would be effective to give various types of feedback in the classroom.

To maximize the effectiveness of studying abroad, it would be ideal to include some classroom instruction or a series of instructional sessions before and during the study abroad period. Prior to departure, a pre-study abroad instruction session would be valuable in terms of employing instruction and raising students' awareness of input. In these sessions, students could perform role-plays related to some situations with a special focus on the difficulty of expressing their intention in a situationally appropriate way. Teachers would then be able to provide feedback, including metapragmatic information, to help their students realize what they did well and what they could change along with reasons explaining why the relevant aspects should be changed. By doing so, students' awareness could be raised so that they would be able to take advantage of input and output opportunities while studying abroad.

\section{Conclusion}

This study revealed three reasons why the learners changed their production of speech acts after completing a study abroad program: observation of input, instruction, and learning from responses to output. Although input is important, it is not the only way to learn new expressions; rather, instruction and providing opportunities for output are also necessary. Indeed, relying solely on input has some limitations and can lead to misunderstandings or impoliteness when the meaning and implications of a word or phrase is not clearly communicated by English speakers. Therefore, classroom instruction that includes negative feedback is also an integral part of language learning.

This study has some limitations. First, the setting of the role-play required more concrete description to precisely control the scenario, especially the relationship between interlocutors. Each human relationship imagined by the participants might be different and might affect language production. Second, the follow-up interviews should have been conducted immediately 
after the role-play to guarantee the validity of the data. Moreover, it would have been better to ask the participants to review their performance by watching the video recording. Last, the paper only discussed two participants in detail due to space limitations. Further research should be done to include data from other participants who were not included in this paper to verify the results of the current study.

\section{Note}

1. Complaints and apologies were also part of the original study but were removed due to space limitations.

Emi Fukasawa is a lecturer in the Center for Language Education and Research at Sophia University. Her research interest is in the development of interlanguage pragmatics.

\section{References}

Alcón Soler, E. (2012). Teachability and bilingualism effects on third language learners' pragmatic knowledge. Intercultural Pragmatics, 9, 511-541. https:// doi.org/10.1515/ip-2012-0028

Bardovi-Harlig, K. (2013). Developing L2 pragmatics. Language Learning, 63, 68-86. https://doi.org/10.1111/j.1467-9922.2012.00738.x

Bardovi-Harlig, K., \& Bastos, M. T. (2011). Proficiency, length of stay, and intensity of interaction and the acquisition of conventional expressions in L2 pragmatics. Intercultural Pragmatics, 8, 347-384. https://doi.org/10.1515/iprg.2011.017

Bardovi-Harlig, K., \& Hartford, B. (1991). Saying "no" in English: Native and nonnative rejections. In L. Bouton \& Y. Kachru (Eds.), Pragmatics and language learning (Vol. 2, pp. 41-57). Urbana: University of Illinois.

Blum-Kulka, S. (1982). Learning how to mean in a second language: A study of the speech act performance of learners of Hebrew as a second language. Applied Linguistics, 3, 29-59. https://doi.org/10.1093/applin/III.1.29

Cook, H. M. (2001). Why can't learners of JFL distinguish polite from impolite speech styles? In K. R. Rose \& G. Kasper (Eds.), Pragmatics in language teaching (pp. 80-102). New York, NY: Cambridge University Press. https://doi. org/10.1017/CB09781139524797.009

Dewey, D. P., Bown, J., Baker, W., Martinsen, R. A., Gold, C., \& Eggett, D. (2014). Language use in six study abroad programs: An exploratory analysis of possible predictors. Language Learning, 64, 36-71. https://doi.org/10.1111/lang.12031 
Ellis, R., Loewen, S., \& Erlam, R. (2006). Implicit and explicit corrective feedback and the acquisition of L2 grammar. Studies in Second Language Acquisition, 28, 339-368. https://doi.org/10.1017/S0272263106060141

Fukuya, Y. J., \& Martínez-Flor, A. (2008). The interactive effects of pragmaticeliciting tasks and pragmatic instruction. Foreign Language Annals, 41, 478-500. https://doi.org/10.1111/j.1944-9720.2008.tb03308.x

Gass, S. M. (1997). Input, interaction, and the second language learner. https://doi. org/10.4324/9780203053560

Hassall, T. (2006). Learning to take leave in social conversations: A diary study. In M. A. DuFon \& E. Churchill (Eds.), Language learners in study abroad contexts (pp. 31-58). https://doi.org/10.21832/9781853598531-006

Isabelli-García, C. (2006). Study abroad social networks, motivation and attitudes: Implications for second language acquisition. In M. A. DuFon \& E. Churchill (Eds.), Language learners in study abroad contexts (pp. 231-258). https://doi. org/10.21832/9781853598531-013

Kondo, S. (2008). Effects of pragmatic development through awareness-raising instruction: Refusals by Japanese EFL learners. In E. Alcón Soler \& A. MartínezFlor (Eds.), Investigating pragmatics in foreign language learning, teaching and testing (pp. 153-177). https://doi.org/10.21832/9781847690869-010

Leech, G. N. (1983). Principles of pragmatics. https://doi.org/10.4324/9781315835976

Martínez-Flor, A. (2012). Examining EFL learners' long-term instructional effects when mitigating requests. In M. Economidou-Kogetsidis \& H. Woodfield (Eds.), Interlanguage request modification (pp. 243-274). https://doi.org/10.1075/ pbns.217.08mar

Matsumura, S. (2003). Modelling the relationships among interlanguage pragmatic development, L2 proficiency, and exposure to L2. Applied Linguistics, 24, 465 491. https://doi.org/10.1093/applin/24.4.465

MEXT. (2016). 各試験団体のデー夕によるCEFRとの対照表 [Conversion table of CEFR to other assessments]. Retrieved from http://www.mext.go.jp/b_menu/shingi/ chousa/shotou/117/shiryo/__icsFiles/afieldfile/2016/05/24/1368985_15_1. pdf

Roever, C. (2011). Testing of second language pragmatics: Past and future. Language Testing, 28, 463-481. https://doi.org/10.1177/0265532210394633

Schauer, G. (2009). Interlanguage pragmatic development: the study abroad context. London, England: Continuum. 
Schmidt, R. W. (1990). The role of consciousness in second language learning. Applied Linguistics, 11, 129-158. https://doi.org/10.1093/applin/11.2.129

Schmidt, R. (1993). Consciousness, learning and interlanguage pragmatics. In G. Kasper \& S. Blum-Kulka (Eds.), Interlanguage pragmatics. (pp. 21-42). New York, NY: Oxford University Press.

Schmidt, R. (2001). Attention. In P. Robinson (Ed.), Cognition and second language instruction (pp. 3-32). https://doi.org/10.1017/cbo9781139524780.003

Schmidt, R., \& Frota, S. (1986). Developing basic conversational ability in a second language: A case study of an adult learner of Portuguese. In R. R. Day (Ed.), Talking to learn: Conversation in second language acquisition (pp. 237-326). Rowley, MA: Newbury House.

Segalowitz, N., \& Freed, B. F. (2004). Context, contact, and cognition in oral fluency acquisition: Learning Spanish in at home and study abroad contexts. Studies in Second Language Acquisition, 26, 173-199. https://doi.org/10.1017/ S0272263104262027

Swain, M. (1985). Communicative competence: Some roles of comprehensible input and comprehensible output in its development. In S. Gass \& C. Madden (Eds.), Input in second language acquisition (pp. 235-253). Rowley, MA: Newbury House.

Swain, M., \& Lapkin, S. (1995). Problems in output and the cognitive processes they generate: A step towards second language learning. Applied Linguistics, 16, 371-391. https://doi.org/10.1093/applin/16.3.371

Taguchi, N. (2008). Cognition, language contact, and development of pragmatic comprehension in a study-abroad context. Language Learning, 58, 33-71. https://doi.org/10.1111/j.1467-9922.2007.00434.x

Taguchi, N. (2012). Context, individual differences and pragmatic competence. https://doi.org/10.21832/9781847696106

Taguchi, N. (2015). Developing interactional competence in a Japanese study abroad context. https://doi.org/10.21832/9781783093731

Takahashi, S. (2001). The role of input enhancement in developing pragmatic competence. In K. Rose \& G. Kapser (Eds.), Pragmatics in language teaching (pp. 171-199). https://doi.org/10.1017/CB09781139524797.014

Takahashi, S. (2005). Pragmalinguistic awareness: Is it related to motivation and proficiency? Applied Linguistics, 26, 90-120. https://doi.org/10.1093/applin/ amh040 
Takahashi, S. (2010a). The effect of pragmatic instruction on speech act performance. In A. Martínez-Flor \& E. Usó-Juan (Eds.), Speech act performance: Theoretical, empirical and methodological issues (pp. 127-142). https://doi. org/10.1075/llt.26.08tak

Takahashi, S. (2010b). Assessing learnability in second language pragmatics. In A. Trosborg (Ed.), Pragmatics across languages and cultures (pp. 391-421). https://doi.org/10.1515/9783110214444.3.391

Takahashi, S. (2012). Individual differences and pragmalinguistic awareness: A structural equation modeling approach. Language, Culture, and Communication, 4, 103-125.

Takahashi, S. (2013). Awareness and learning in second language pragmatics. Language, Culture, and Communication, 5, 53-76.

Takahashi, S. (2015). The effects of learner profiles on pragmalinguistic awareness and learning. System, 48, 48-61. https://doi.org/10.1016/j.system.2014.09.004

Takahashi, S. (2017). Pragmatics-grammar interface in pragmalinguistic awareness and learning. Language, Culture, and Communication, 9, 87-111.

Takimoto, M. (2006). The effects of explicit feedback and form-meaning processing on the development of pragmatic proficiency in consciousness-raising tasks. System, 34, 601-614. https://doi.org/10.1016/j.system.2006.09.003

Trosborg, A. (1995). Interlanguage pragmatics: Requests, complaints and apologies. Berlin, Germany: Mouton Gruyter.

Yuan, Y. (2001). An inquiry into empirical pragmatics data-gathering methods: Written DCTs, oral DCTs, field notes, and natural conversations. Journal of Pragmatics, 33, 271-292. https://doi.org/10.1016/S0378-2166(00)00031-X

Wilkinson, S. (1998). On the nature of immersion during study abroad: Some participant perspectives. Frontiers: The Interdisciplinary Journal of Study Abroad, 4, 121-138. 


\section{Appendix}

\section{Descriptions of the Situations Given to the Students in the Role-Play (Original in Japanese)}

\begin{tabular}{|c|c|}
\hline $\begin{array}{l}\text { 友人に } \\
\text { 断る }\end{array}$ & $\begin{array}{l}\text { あなたは大学生です。来週はレポートの提出日があるのですが、まだ } \\
\text { 終わっていません。金曜日の夜は図書館で調べ物をしようと思ってい } \\
\text { ます。大学の友人、デイビッドが話しかけてきます。 }\end{array}$ \\
\hline $\begin{array}{l}\mathrm{Re} \\
\text { to }\end{array}$ & $\begin{array}{l}\text { You are a university student. You are working on a report. Next } \\
\text { week the submission is due, but you have not finished it yet. } \\
\text { You are thinking that you will do research in the library on } \\
\text { Friday night. Your friend, David from university is going to talk } \\
\text { to you now. }\end{array}$ \\
\hline $\begin{array}{l}\text { 先生に } \\
\text { 断る }\end{array}$ & $\begin{array}{l}\text { あなたは大学生です。大学であなたのゼミの先生である、スノー教授 } \\
\text { と偶然会いました。金曜日のお昼は友人と食べる約束をしています。 } \\
\text { スノー教授が話しかけてきます。 }\end{array}$ \\
\hline $\begin{array}{l}\text { Refu } \\
\text { to } \\
\text { teac }\end{array}$ & $\begin{array}{l}\text { rsity, you just come across } \\
\text { teacher. You already have } \\
\text { on Friday. Professor Snow }\end{array}$ \\
\hline $\begin{array}{l}\text { 友人 } \\
\text { 頼す }\end{array}$ & $\begin{array}{l}\text { 崖を休みました。そこで、休 } \\
\text { する友人デイビッドに借りた } \\
\text { す。 }\end{array}$ \\
\hline $\begin{array}{l}\text { Requ } \\
\text { to fr }\end{array}$ & $\begin{array}{l}\text { You are a university student. You were absent from the last } \\
\text { class. You want to borrow the notebook from your friend, } \\
\text { David, who is taking the same class. You are going to talk to } \\
\text { him. }\end{array}$ \\
\hline $\begin{array}{l}\text { 先生に } \\
\text { 頼する }\end{array}$ & ふたは大学生です。もうすぐレ \\
\hline $\begin{array}{l}\text { Request } \\
\text { to } \\
\text { teacher }\end{array}$ & $\begin{array}{l}\text { You are a university student. The deadline of your } \\
\text { soon. You are looking for a book to write the essay. } \\
\text { want to borrow the book from Professor Snow. You }\end{array}$ \\
\hline
\end{tabular}

